\section{Cowpea yield and quality after application of desiccating herbicides}

\author{
Jeovane Nascimento Silva ${ }^{1}$ (D) Estevam Matheus $\operatorname{Costa}^{1}{ }^{(\mathbb{D})}$, Leandro Spíndola \\ Pereira $^{1}{ }^{\mathbb{D}}$, Elaine Cristina Zuquetti Gonçalves ${ }^{1} \mathbb{D}$, Jacson Zuchi ${ }^{1}$ iD, Adriano \\ Jakelaitis $^{1 *(i D)}$
}

\begin{abstract}
The aim of this study was to evaluate the effects of pre-harvest desiccant herbicides on the yield and the physiological and technological quality of cowpea seeds after harvest and after storage. The experiment was conducted in a randomized block design with four replications. A split-plot design $(6 \times 2)$ was composed of the desiccant herbicides flumioxazin (30 $\mathrm{g}$ ai.ha-1 $)$, glufosinate ammonium (500 $\mathrm{g}$ ai.ha-1), paraquat (400 g ai.ha ${ }^{-1}$ ), saflufenacil ( $70 \mathrm{~g}$ ai.ha ${ }^{-1}$ ), and carfentrazone ( $24 \mathrm{~g}$ ai.ha ${ }^{-1}$ ) and an untreated control, as well as two seed evaluation periods, at harvest and six months after $h$ arvest. Desiccants were applied at the $R_{5}$ stage. The desiccants affected the yield, classification, color, and physiological quality of seeds of 'BRS Guariba'. The glufosinate ammonium and paraquat herbicides compromised seed physiological quality. Flumioxazin did not affect seed yield components, color, and physiological quality. Storage at $20^{\circ} \mathrm{C}$ for six months affected seed physiological quality.
\end{abstract}

Index terms: Vigna unguiculata L., vigor, storage.

\section{Rendimento e qualidade de sementes de feijão-caupi após a aplicação de herbicidas dessecantes}

RESUMO: O objetivo deste estudo foi avaliar os efeitos de herbicidas dessecantes aplicados em pré-colheita sobre o rendimento, a qualidade fisiológica e tecnológica de sementes de feijão-caupi após a colheita e o armazenamento. O experimento foi conduzido em delineamento de blocos ao acaso, com quatro repetições. Adotou-se o esquema de parcelas subdivididas ( $6 \times 2$ ), compostas pelos herbicidas dessecantes: flumioxazim (30 $\mathrm{g}^{\text {i.a.ha-1 }}$ ), $^{-1}$ glufosinato de amônio (500 g i.a.ha ${ }^{-1}$ ), paraquate (400 g i.a.ha-1), saflufenacil (70 g i.a.ha-1), carfentrazone ( $24 \mathrm{~g}$ i.a.ha ${ }^{-1}$ ) e uma testemunha não tratada, por duas épocas de avaliação das sementes: colheita e seis meses após a colheita. A aplicação dos dessecantes ocorreu no estágio R5. Os dessecantes afetaram o rendimento, a classificação, a coloração e a qualidade fisiológica das sementes da cultivar BRS Guariba. Os herbicidas glufosinato de amônio e paraquate comprometeram a qualidade fisiológica das sementes. O flumioxazin não afetou os componentes de rendimento, a coloração e a qualidade fisiológica. $\mathrm{O}$ armazenamento a $20{ }^{\circ} \mathrm{C}$ por seis meses afetou a qualidade fisiológica das sementes.

Termos para indexação: Vigna unguiculata L., vigor, armazenamento.
Journal of Seed Science, v.42, e202042019, 2020

http://dx.doi.org/10.1590/ 2317-1545v42228204
${ }^{*}$ Corresponding author
E-mail: adriano.jakelaitis@ifgoiano.
edu.br

Received: 3/09/2019. Accepted: 17/02/2020.

${ }^{1}$ Diretoria de Pós-Graduação, Pesquisa e Inovação, Instituto Federal Goiano Campus Rio Verde, Caixa Postal 66, Cep: 75901-970, Rio Verde, Goiás, Brasil. 


\section{INTRODUCTION}

In Brazil, cowpea (Vigna unguiculata L.) occupied a planted area of 1516 thousand hectares, with production of 789.8 thousand (metric) tons of grain in 2018 (CONAB, 2019). In the state of Goias, average yield of cowpea for the 2019 crop season is estimated to be $1260 \mathrm{~kg}^{-h^{-1}}{ }^{-1}$, whereas the average yield for Brazil is $521 \mathrm{~kg} \cdot \mathrm{ha}^{-1}$ (CONAB, 2019). Due to development of varieties with traits that favor mechanized harvest, the crop is expanding in the Center-West region of Brazil, although production is still mainly concentrated in the Northeast region (CONAB, 2019).

Modernization of Brazilian agriculture has required changes to improve the production process and ensure seed quality. High quality seeds assume a fundamental role for production companies. Plants generally remain in the field for some time beyond their physiological maturity, exposed to environmental variations that can compromise their physiological quality (Paiva et al., 2018). One of the significant difficulties during harvest of cowpea seeds is their lack of uniform physiological maturity.

High quality seeds depend on harvest occurring at the ideal time, frequently when physiological maturity is reached, coinciding with maximum accumulation of seed dry matter, high vigor, and high germination (Lima et al., 2018). One of the alternatives is desiccant herbicide prior to harvest, which can reduce exposure of seeds to unfavorable environmental conditions.

Desiccant herbicides has been adopted in some dry edible bean (common bean) producing regions (Kappes et al., 2012). Desiccant herbicides applied in an appropriate manner promote uniformity in crop maturation, allow earlier harvest, and do not cause yield loss; and seeds of high physiological quality can be obtained (Lamego et al., 2013). Nevertheless, some important aspects should be taken into consideration in desiccant herbicide, such as the mode of action of the product, the phenological stage the crop is in, and the effect on seed yield, germination, and vigor (Finoto et al., 2017).

In addition, desiccation can interfere in the physiological quality of cowpea seeds during storage. How seed quality is affected depends on the genotype, the edaphic and climatic conditions, and biotic factors. Deterioration in quality can occur during storage under inadequate temperature and moisture conditions (Zuchi et al., 2013). Such conditions cannot be prevented, only minimized.

In this context, the aim of this study was to evaluate the effects of desiccant herbicides applied prior to harvest on the yield and physiological and technological quality of cowpea seeds at the time of harvest and after six months of storage.

\section{MATERIALS AND METHODS}

The 'BRS Guariba' cowpea crop was grown in a field in Rio Verde, GO, at the coordinates $17^{\circ} 48^{\prime} 67^{\prime \prime} \mathrm{S}$ and $50^{\circ} 54^{\prime} 18^{\prime}$ $\mathrm{W}$ and altitude of $754 \mathrm{~m}$. Soil in the area (Latossolo Vermelho distroférrico) at the depth of 0-20 cm had the following

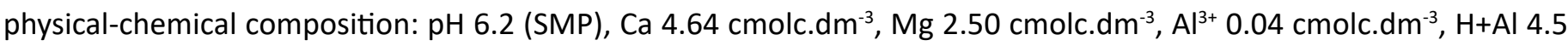
cmolc. dm ${ }^{-3}$, CEC $12.1 \mathrm{cmolc} \mathrm{dm}^{-3}, \mathrm{~K} 0.46 \mathrm{cmolc}^{-\mathrm{dm}^{-3}}, \mathrm{P}$ (Mehlich) $13.1 \mathrm{mg} . \mathrm{dm}^{-3}$, organic matter $3.62 \mathrm{mg} . \mathrm{dm}^{-3}, \mathrm{Zn} 4.5$ $\mathrm{mg} . \mathrm{dm}^{-3}$, base saturation $62.8 \%$, aluminum saturation $0.5 \%$, clay $64.5 \%$, silt $10 \%$, and sand $25.5 \%$.

A randomized block experimental design was adopted in split plots $(6 \times 2)$ with four replications. The first factor was constituted by application of the desiccant herbicides flumioxazin (Flumyzin 500, $500 \mathrm{~g}$ a.e. $\mathrm{L}^{-1} \mathrm{WP}$, Sumito Chemical do Brasil) at 60 g.ha ${ }^{-1}$, glufosinate ammonium (Liberty ${ }^{\circledR}, 200$ g a.e.L ${ }^{-1}$ SL, Basf) at 2.5 L.ha $^{-1}$, paraquat (Gramoxone ${ }^{\circledR}, 200$

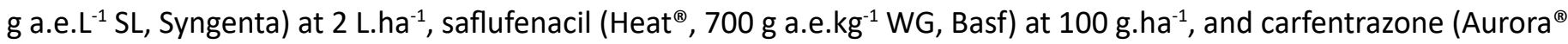
$400 \mathrm{EC}, 400 \mathrm{~g}$ a.e. $\mathrm{L}^{-1} \mathrm{EC}, \mathrm{FMC}$ ) at $60 \mathrm{~mL} \cdot \mathrm{ha}^{-1}$, and an untreated control. The second factor was constituted by the time of seed quality evaluation - after harvest and six months after harvest (6 MO). Each plot had an area of $24.5 \mathrm{~m}^{2}$, with four 7-m-length rows and between-row spacing of one half meter. The area of the plot used for data collection was the central five meters of the two central rows. 
The cowpea seeds were treated with $100 \mathrm{~g}$ de pyraclostrobin + methyl thiophanate + fipronil (Standak ${ }^{\circledR}$ Top) for $100 \mathrm{~kg}$ of seed and then inoculated with $300 \mathrm{~mL}$ of Bradyrhizobium spp. for $100 \mathrm{~kg}$ of seed. Seeds were sown on March 17, 2018, with twelve seeds per linear meter at a depth of $3 \mathrm{~cm}$. Fertilization at planting was $300 \mathrm{~kg}^{-h^{-1}}$ of $^{-1}$ the formulation 04-14-08 (Souza and Lobato, 2004).

At thirteen days after emergence (DAE), the commercial mixture of bentazon + imazamox (Amplo ${ }^{\circledR}$ ) was applied at the rate of $1 \mathrm{~L}$ of the commercial product per hectare, and, at seventeen DAE, haloxyfop-p-methyl (Verdict ${ }^{\circledR} \mathrm{R}$ ) was applied at the rate of $0.4 \mathrm{~L}$ of the commercial product per hectare. During the crop cycle, one application was made of the insecticide lambda-cyhalothrin + chlorantraniliprole (Ampligo ${ }^{\circledR}$ ) at the rate of $0.16 \mathrm{~L}$ of the commercial product per hectare for control of Spodoptera eridania (Cramer) and another of the fungicide fluxapyroxad + pyraclostrobin (Orkestra ${ }^{\circledR} \mathrm{SC}$ ) at the rate of $0.3 \mathrm{~L}$ of commercial product per hectare for control of Erysiphe polygoni.

The herbicides were applied 78 days after sowing (DAS) at the $R_{5}$ stage, when the pods were at physiological maturity with brown to tan color and seeds had $70 \%$ moisture content (Carvalho and Nakagawa, 2012). The herbicides were applied with a $\mathrm{CO}_{2}$ pressurized backpack sprayer, model $\mathrm{TT} 110^{\circ} 03$ with four spray tips, at a constant pressure of 2.5 bar and spray volume of 200 L.ha $^{-1}$.

The seed moisture content in each plot was monitored, establishing the point of harvest when seeds had moisture levels near $11 \%$. Upon reaching this level, plants were cut at soil level and the pods were removed and threshed manually. The seeds were dried in a laboratory oven at $35^{\circ} \mathrm{C}$ until reaching $11 \%$ moisture.

The number of days of anticipation of harvest (earlier harvest in days) was determined by counting the days from application of desiccation herbicides up to when the plants were completely defoliated and grain moisture was in the range of $13-15 \%$ moisture compared to the day of harvest of the untreated control (Brasil, 2009; Krzyzanowski et al., 2015).

One thousand seed weight was determined as recommended in the Rules for Seed Testing (Brasil, 2009), with eight replications of 100 seeds, extrapolating the values to 1000 seeds. In a parallel manner, yield in kg.ha ${ }^{-1}$ was determined by weighing all the seeds obtained from the area used for data collection and extrapolating.

The seeds collected from the area used for data collection were cleaned in sieves and classified through determination of the proportion of seeds per sieve. The samples from each plot were weighed, passed through a set of metallic sieves with mesh sizes of $7.5 \mathrm{~mm}$ oval, $4.5 \mathrm{~mm}$ oblong, $3.5 \mathrm{~mm}$ oblong, $3.5 \mathrm{~mm}$ oval, and bottom collector (Brasil, 2009). The seeds that passed through a sieve with oblong mesh of $3 \mathrm{~mm}$ width and $19 \mathrm{~mm}$ length were considered immature, with incomplete physiological development. Those that were retained in sieves with meshes of $4.5 \mathrm{~mm}$ or more were considered healthy, with complete physiological development (Knabben and Costa, 2012). The samples were placed in plastic bags and then in BOD $\left(20^{\circ} \mathrm{C}\right)$, where they remained throughout the period of evaluations. Relative humidity $(\mathrm{RH})$ and temperature were registered by a digital data logger (accuracy: $0.1{ }^{\circ} \mathrm{C} ; 5.0 \% \mathrm{RH}$ ).

Physiological quality was checked after harvest and at six months of storage through the following tests: germination, seedling dry matter, root and shoot length, accelerated aging, emergence in sand substrate, emergence speed index, electrical conductivity, hydration coefficient, and grain color. Evaluations were conducted with duplicate sets of fifty seeds for each replication.

Germination (G): First, seeds were treated with $45 \mathrm{~g}$ a.i. of carbendazim $+105 \mathrm{~g}$ a.i. of thiram for $100 \mathrm{~kg}$ of seed and, after that, the seeds were sown in germitest paper moistened with distilled water in the amount of 2.5 times the weight of the dry paper. The rolls were placed separately by field replication in plastic bags and kept at $25^{\circ} \mathrm{C}$ in a germination chamber for eight days, at which time the percentage of normal seedlings was determined (Brasil, 2009).

First germination count (FGC): This was performed together with the germination tests. One count was performed on the fifth day after setting up the germination test (Brasil, 2009), and the second germination count was performed on the eighth day after setting up the germination test. After counting, calculations of germination percentage [as recommended by the Brazilian Ministry of Agriculture (Ministério da Agricultura, Pecuária e Abastecimento - MAPA)] were carried out for percentage values greater than 80 (Brasil, 2009). 
Seedling dry matter (SDM): Fourteen seedlings per experimental unit were used. Cotyledons were extracted and the seedlings were then placed in Kraft paper bags in an air circulation laboratory oven at $80^{\circ} \mathrm{C}$ for 24 hours. After drying, they were weighed, and results were expressed in mg per seedling (Vieira and Krzyzanowski, 1999).

Seedling length (SL): Fourteen seedlings from the germination test of each experimental unit were used. Evaluation was carried out on the eighth day after setting up the germination test, and seedlings classified as normal in the germination test were selected. Total length of the seedling was determined from the tip of the main root up to the point of connection of the cotyledons with the aid of a millimeter ruler at eight days after sowing. The mean total length of fourteen seedlings was obtained. The shoot (SHL) and root (RL) were also evaluated (Vieira and Krzyzanowski, 1999).

Accelerated aging test: The seeds were placed in a gerbox transparent plastic box with an aluminum screen inside. Distilled water $(40 \mathrm{~mL})$ was added to each gerbox, and the seeds were arranged on the screen. Lids were placed on the boxes and they were placed in a germination chamber kept at $41{ }^{\circ} \mathrm{C}$ for 48 hours (Marcos-Filho, 1999). After this aging period, the germination test was performed on the seeds, as described above. Five days after sowing in germitest paper, the results of percentage of normal seedlings were obtained (Brasil, 2009).

Emergence test: This was conducted in a greenhouse, with four replications of fifty seeds. Seeds were sown in sand at a depth of $3 \mathrm{~cm}$. The environment was irrigated by an automatic sprinkler four times a day. Emerged seedlings were counted daily up to numerical stabilization, which occurred at eight days after emergence. Seedlings with cotyledons in the horizontal position were considered to have emerged. The results of the emergence speed index were calculated according to Maguire (1962).

Conductivity test: This was carried out with eight replications of fifty seeds from each treatment. Seeds were first weight on a precision balance $(0.01 \mathrm{~g})$ and placed in plastic cups containing $75 \mathrm{~mL}$ of distilled and deionized water; they were kept in imbibition in BOD at $25^{\circ} \mathrm{C}$. After 24 hours, electrical conductivity was read using a Technal TEC-4MP digital conductivity meter. Results were expressed in $\mu \mathrm{S} \mathrm{cm} \mathrm{cm}^{-1} \cdot \mathrm{g}^{-1}$ of seed (Vieira and Krzyzanowski, 1999).

Determination of hydration coefficient: In this test, $15 \mathrm{~g}$ of seeds soaked in $60 \mathrm{~mL}$ of distilled water (1:4 proportion) at ambient temperature $\left(25^{\circ} \mathrm{C}\right)$ were used. After twelve hours, maceration water was removed, followed by removal of free water, leaving each sample for two minutes on absorbent paper before weighing. Weight gain was considered as the amount of water absorbed, and expressed as the hydration coefficient $(\mathrm{HC})$, calculated by the following equation: $\mathrm{HC}=\mathrm{WW} / \mathrm{WS} \times 100$, where $\mathrm{HC}$ is the hydration coefficient, WW is the weight of the seed after hydration, and WS is the weight of the seed before hydration (El-Refai et al., 1988; Nasar-Abbas et al., 2008).

Color of seed coat of whole, uniform seeds: This was determined using a ColorFlex EZ colorimeter with a Hunter color system, which indicates colors in a three-dimensional system. The vertical $L^{*}$ axis indicates the color of the sample from white to black, the "a" axis from the color red to green, and the "b" axis from yellow to blue (AfonsoJúnior and Corrêa, 2003). For better characterization, the seeds were evaluated in the resting position at two different points, subsequently calculating the mean value of each seed. The difference in color $\left(\Delta \mathrm{E}^{*}\right)$ was obtained by the equation $\Delta E^{*}=\left[\left(\Delta L^{*}\right) 2+\left(\Delta a^{*}\right) 2\right] 0.5$, where $\Delta E^{*}=$ value for color difference; $\Delta L^{*}=$ difference between the $L^{*}$ of the initial sample and the $L^{*}$ of the stored sample; $\Delta a^{*}=$ difference between the $a^{*}$ of the initial sample and the a* of the stored sample.

The Shapiro-Wilk test was performed on the data and, when significant $(p \leq 0.05)$, they were transformed in square root $(x+0.5)$ for analysis. After that, analysis of variance was performed by the $F$ test $(p \leq 0.05)$ and, when significant, they were compared by the Tukey test $(p \leq 0.05)$.

\section{RESULTS AND DISCUSSION}

Significant effects were observed for the variables earlier harvest in days (EHD), thousand seed weight (1000SW), seed yield (SY), sieve of $4.5 \mathrm{~mm}$ mesh (S4.5) and sieve of $3.5 \mathrm{~mm}$ mesh with oblong shape (S3.5 OB) for the herbicides, and significant effects were not found for seeds classified in the sieve of $7.5 \mathrm{~mm}$ oval mesh (S7.5) and the sieve of $3.5 \mathrm{~mm}$ oval 
mesh (S3.5 O) and bottom collector (Table 1). With application of paraquat, harvest was ten days earlier compared to the untreated control; however, the more intense effect of the herbicide led to lower SY and 1000SW (Table 1).

The degree of desiccation is related to the damage the herbicide causes to cell membranes, bringing about drying, leaf drop, and, simultaneously, water loss in seeds and low seed weight (Tarumoto et al., 2015). In the specific case of materials of indeterminate growth habit and lack of uniform maturation, such as 'BRS Guariba', this effect can be more intense, as observed for paraquat, for which the decline in SY values was approximately $46 \%$ compared to the control. For the saflufenacil and glufosinate ammonium herbicides, which also promoted EHD, the same response was observed, but in lower intensity in relation to the others (Table 1).

The intensity of the effects of the herbicides on cowpea plants also affected seed classification. In the treatments with herbicides that led to greater EHD in cowpea plants and, consequently, lower SY and 1000SW, seeds were mostly retained in the $3.5 \mathrm{~mm}$ oblong mesh sieve (Table 1). In the sieves with larger meshes, such as the $4.5 \mathrm{~mm}$ mesh with oblong shape, a larger number of seeds were found coming from plants that did not receive herbicides or coming from treatments with flumioxazin (Table 1). This result is important for seed production because seeds retained in sieves of higher numbering generally exhibit greater vigor in relation to the soybean varieties retained in sieves of greater size (Mathias and Coelho, 2018).

The herbicides used for plant desiccation generally affected germination, shoot length (SHL) and root length (RL) of seedlings, and seedling dry matter (SDM), but did not affect percentage of emergence (E) (Tables 2 and 3). The use of paraquat and glufosinate ammonium reduced germination of the cowpea seeds evaluated after harvest in relation to the untreated control and to the other herbicides (Table 2).

Studies indicate that herbicides recommended for pre-harvest desiccation of crops have reduced seed germination due to their harmful effects on seed formation. For soybean, glufosinate ammonium was the treatment least recommended for desiccation, due to lower values of seed germination percentage (Delgado et al., 2015; Souza et al., 2017). Desiccating products have different mechanisms and degrees of desiccation, intrinsically related to the injury caused to cell membranes, allowing rapid water loss. The process of seed and plant water loss should be known for the specific crop. The particular characteristics of each product and application rates can bring about water losses during harvest that can directly affect seed physical and chemical quality (Lamego et al., 2013).

The use of desiccants in pre-harvest did not affect the shoots and roots of seedlings grown from the seeds harvested. However, after six months of storage, the shoot length of seeds from all the treatments increased, which consequently

Table 1. Earlier harvest in days (EHD), seed yield (SY), 1000 seed weight (1000SW), and classification of seeds by means of sieves of $7.5 \mathrm{~mm}$ oval mesh (S7.5), $4.5 \mathrm{~mm}$ oblong mesh (S4.5), $3.5 \mathrm{~mm}$ oblong mesh (S3.5 OB), 3.5 $\mathrm{mm}$ oval mesh ( $\mathrm{S} 3.5 \mathrm{O})$, and bottom collector of cowpea as a result of desiccant herbicide treatments.

\begin{tabular}{|c|c|c|c|c|c|c|c|c|}
\hline \multirow{2}{*}{ Desiccant } & \multirow{2}{*}{$\mathrm{EHD}^{1 /}$} & $\mathrm{SY}^{1 /}$ & $1000 S W$ & $\mathrm{~S} 7.5^{1 /}$ & S4. $.5^{1 /}$ & $\mathrm{S} 3.5 \mathrm{OB}^{1 /}$ & $\mathrm{S} 3.5 \mathrm{O}^{1 /}$ & BOTTOM $^{1 /}$ \\
\hline & & $\left(\mathrm{kg} \cdot \mathrm{ha}^{-1}\right)$ & \multicolumn{6}{|c|}{-- } \\
\hline Control & $0.00 \mathrm{e}^{2 /}$ & 1315.65 a & 194.62 a & $4.35 \mathrm{a}$ & 573.75 a & $55.47 \mathrm{bc}$ & $3.82 \mathrm{a}$ & $0.52 \mathrm{a}$ \\
\hline Flumioxazin & $2.00 \mathrm{~d}$ & $1219.15 \mathrm{ab}$ & 197.68 a & $6.92 \mathrm{a}$ & $531.25 a b$ & $55.70 \mathrm{bc}$ & $6.75 a$ & $1.90 \mathrm{a}$ \\
\hline Glufosinate ammonium & $4.00 \mathrm{c}$ & $855.45 \mathrm{abc}$ & $176.04 a b$ & $4.32 \mathrm{a}$ & $303.32 \mathrm{~cd}$ & $101.10 \mathrm{ab}$ & $11.40 \mathrm{a}$ & $0.17 \mathrm{a}$ \\
\hline Paraquat & $10.00 \mathrm{a}$ & $704.75 \mathrm{c}$ & $164.38 b$ & $0.65 a$ & $207.62 \mathrm{~d}$ & $120.30 \mathrm{a}$ & $15.35 \mathrm{a}$ & $1.80 \mathrm{a}$ \\
\hline Saflufenacil & $6.00 \mathrm{~b}$ & 791.65 bc & $184.92 a b$ & $3.90 \mathrm{a}$ & $339.97 \mathrm{bcd}$ & $62.85 b c$ & 18.15 a & $0.65 a$ \\
\hline Carfentrazone & $0.00 \mathrm{e}$ & $1015.75 a b c$ & $195.13 \mathrm{a}$ & $2.87 \mathrm{a}$ & $433.90 \mathrm{abc}$ & $45.15 \mathrm{c}$ & $3.52 \mathrm{a}$ & $0.00 \mathrm{a}$ \\
\hline CV (\%) & 0.00 & 10.02 & 2.66 & 50.31 & 11.53 & 15.77 & 40.10 & 40.34 \\
\hline
\end{tabular}

${ }^{1}$ Data transformed in square root $(x+0.5)$.

${ }^{2}$ Mean values followed by the same letters are statistically equal by the Tukey test $(p \leq 0.05)$. 
affected root growth. The desiccant herbicide treatments that were most harmful were paraquat and saflufenacil. Consequently, these treatments had the greatest effect on root growth of seeds after storage, and paraquat was the herbicide that most affected germination and root growth (Table 3). Tests related to length of seedlings or their parts are effective for detecting subtle differences in seed vigor (Vanzolini et al., 2007).

After storage of the cowpea seeds, the effects of the desiccants on seed germination were observed (Table 2). Pre-harvest desiccation with glufonisate ammonium carried out on soybean cultivars harmed the physiological quality of their seeds after six months of storage (Silva et al., 2016). Marcos-Filho (2015) confirms that the use of herbicides with contact action on plants reduces the seed germination. Prolonging these effects does not interfere in transfer of dry matter during the maturation process, and this leads to more vigorous seeds with the energy necessary to maintain vital functions during storage.

Table 2. Percentage of emergence (E), germination of cowpea seeds evaluated after harvest and after six months of storage $(6 \mathrm{MO})$ as a result of desiccant herbicide treatments.

\begin{tabular}{lcccc}
\hline \multirow{2}{*}{ Desiccant } & \multicolumn{2}{c}{$\mathrm{E}^{1 /}(\%)$} & \multicolumn{2}{c}{ Germination } \\
\cline { 2 - 6 } & Harvest & $6 \mathrm{MO}$ & Harvest & $6 \mathrm{MO}$ \\
\hline Control & $91^{2 /}$ & 81 & $97 \mathrm{aA}$ & $80 \mathrm{aA}$ \\
Flumioxazin & 85 & 82 & $98 \mathrm{aA}$ & $93 \mathrm{aA}$ \\
Glufosinate ammonium & 61 & 67 & $66 \mathrm{bA}$ & $72 \mathrm{aA}$ \\
Paraquat & 67 & 74 & $63 \mathrm{bB}$ & $83 \mathrm{aA}$ \\
Saflufenacil & 83 & 81 & $88 \mathrm{abA}$ & $72 \mathrm{aA}$ \\
Carfentrazone & 87 & 84 & $81 \mathrm{abA}$ & $84 \mathrm{aA}$ \\
\hline \multicolumn{2}{c}{ CV A (\%) } & \multicolumn{3}{c}{9.15} \\
\hline \multicolumn{2}{c}{ CV B (\%) } & 11.78 & \multicolumn{3}{c}{6.93} \\
\hline
\end{tabular}

${ }^{1}$ Data transformed in square root $(x+0.5)$.

${ }^{2}$ Mean values followed by the same lowercase letters in the columns and uppercase letters in the rows are statistically equal by the Tukey test $(p \leq 0.05)$.

Table 3. Shoot length (SHL), root length (RL), and dry matter (SDM) of seedlings from cowpea seeds evaluated after harvest and after six months of storage $(6 \mathrm{MO})$ as a result of desiccant herbicide treatments.

\begin{tabular}{|c|c|c|c|c|c|c|}
\hline \multirow{2}{*}{ Desiccant } & \multicolumn{2}{|c|}{$\mathrm{SHL}^{1 /}(\mathrm{cm})$} & \multicolumn{2}{|c|}{$\mathrm{RL}^{1 /}(\mathrm{cm})$} & \multicolumn{2}{|c|}{$\operatorname{SDM}^{1 /}(\mathrm{g})$} \\
\hline & Harvest & $6 \mathrm{MO}$ & Harvest & $6 \mathrm{MO}$ & Harvest & $6 \mathrm{MO}$ \\
\hline Control & $3.33 \mathrm{aB}^{2 /}$ & $6.58 \mathrm{aA}$ & $7.54 \mathrm{aA}$ & $5.29 \mathrm{abA}$ & $0.53 \mathrm{aA}$ & $0.74 \mathrm{aA}$ \\
\hline Flumioxazin & $3.40 \mathrm{aB}$ & $8.53 \mathrm{aA}$ & $7.79 \mathrm{aA}$ & $6.49 \mathrm{aA}$ & $0.52 \mathrm{aB}$ & $0.83 \mathrm{aA}$ \\
\hline Glufosinate ammonium & $4.03 \mathrm{aB}$ & $6.60 \mathrm{aA}$ & $4.02 \mathrm{aA}$ & $6.37 \mathrm{abA}$ & $0.43 \mathrm{aB}$ & $0.81 \mathrm{aA}$ \\
\hline Paraquat & $4.41 \mathrm{aB}$ & $8.05 \mathrm{aA}$ & 7.99 aA & $2.70 \mathrm{bB}$ & $0.55 \mathrm{aA}$ & $0.56 \mathrm{aA}$ \\
\hline Saflufenacil & $3.12 \mathrm{aB}$ & $6.86 \mathrm{aA}$ & $6.69 \mathrm{aA}$ & $2.63 \mathrm{bB}$ & $0.44 \mathrm{aA}$ & $0.65 \mathrm{aA}$ \\
\hline Carfentrazone & $2.56 \mathrm{aB}$ & $6.10 \mathrm{aA}$ & $5.73 \mathrm{aA}$ & $3.75 \mathrm{abA}$ & $0.35 \mathrm{aB}$ & $0.69 \mathrm{aA}$ \\
\hline CV A (\%) & \multicolumn{2}{|c|}{18.30} & \multicolumn{2}{|c|}{19.55} & \multicolumn{2}{|c|}{9.15} \\
\hline CV B (\%) & \multicolumn{2}{|c|}{14.53} & \multicolumn{2}{|c|}{14.57} & \multicolumn{2}{|c|}{9.85} \\
\hline
\end{tabular}

${ }^{1}$ Data transformed in square root $(x+0.5)$.

${ }^{2}$ Mean values followed by the same lowercase letters in the columns and uppercase letters in the rows are statistically equal by the Tukey test $(p \leq 0.05)$. 
For the seeds evaluated at crop harvest, effects from the herbicides were not observed on SHL, RL, and SDM of the seedlings; effects were observed only after storage (Table 3). An increase in SHL values was found due to storage for all the treatments tested, whereas an increase in SDM only appeared for the flumioxazin, glufosinate ammonium, and carfentrazone herbicide treatments. Inhibitory effects were observed for RL as a result of seed storage in the paraquat and saflufenacil treatments. The changes observed in this variable stem from the cell disorder in seeds coming from these treatments from the time of early harvest on, bringing about damage to cell components, as found in the electrical conductivity test.

Seed physiological quality is mainly compromised after storage periods, a natural deterioration process inherent to a seed production program (Moussa et al., 2011). In addition, the BRS Guariba cultivar showed greater sensitivity to the storage period, with a lower germination percentage and lower vigor, which hurt initial establishment of seedlings in the field through having less developed roots and, consequently, lower initial biomass accumulation (Boiago et al., 2013).

The accelerated aging test (normal seedlings after accelerated aging - NSAA) was performed on the seeds, which provided the percentage of normal seedlings, confirming the significant interaction between herbicides and the period of evaluation (Table 4).

At the time of crop harvest, the seeds coming from the treatments with paraquat, glufosinate ammonium, and saflufenacil had lower NSAA values compared to the other treatments, and the decrease in NSAA values intensified with storage both for the seeds coming from herbicide treatments and for the seeds from the untreated control. Seeds coming from the treatment with glufosinate ammonium had a percentage of normal seedlings after accelerated aging lower than the percentages from the other treatments. According to Lima et al. (2018), seeds from common bean desiccated with glufosinate ammonium at different time periods have lower NSAA values in relation to the untreated control. Tavares et al. (2016) also observed effects after storage of seeds coming from a treatment with application of paraquat for desiccation of azuki bean.

The greatest rate of water absorption $(\mathrm{HC})$ by seeds was observed in seeds coming from the treatment with paraquat, at both periods of evaluation (Table 4), and effects from storage were not observed. In contrast, effects from storage were observed on reduction in seed moisture. The values were $11.51 \%$ and $10.61 \%$ in the evaluations conducted before and after the six months of storage, respectively.

Table 4. Normal seedlings from accelerated aging (NSAA), water absorption rate (hydration coefficient - HC), and electrical conductivity (EC) of cowpea seeds evaluated after harvest and after six months of storage (6 MO) as a result of desiccant herbicide treatments.

\begin{tabular}{|c|c|c|c|c|c|c|}
\hline \multirow{2}{*}{ Desiccant } & \multicolumn{2}{|c|}{ NSAA (\%) } & \multicolumn{2}{|c|}{$\mathrm{HC}(\%)$} & \multicolumn{2}{|c|}{$\mathrm{EC}\left(\mu \mathrm{S} \mathrm{cm} \mathrm{cm}^{-1} \cdot \mathrm{g}^{-1}\right)$} \\
\hline & Harvest & $6 \mathrm{MO}$ & Harvest & $6 \mathrm{MO}$ & Harvest & $6 \mathrm{MO}$ \\
\hline Control & $90 \mathrm{aA}^{2 /}$ & $40 \mathrm{aB}$ & 225 bA & 229.2 bA & 133.1 bB & $164.8 \mathrm{aA}$ \\
\hline Flumioxazin & 89 aA & $34 \mathrm{aB}$ & 223 bA & 230.2 bA & 118.5 bB & $163.9 \mathrm{aA}$ \\
\hline G. ammonium ${ }^{1}$ & 66 bcA & $23 \mathrm{aB}$ & $230 \mathrm{bA}$ & 235.6 bA & $169.9 \mathrm{aB}$ & $196.0 \mathrm{aA}$ \\
\hline Paraquat & $56 \mathrm{cA}$ & $32 \mathrm{aB}$ & 249 aA & $254.1 \mathrm{aA}$ & $124.1 \mathrm{bB}$ & $179.9 \mathrm{aA}$ \\
\hline Saflufenacil & $57 \mathrm{cA}$ & $37 \mathrm{aB}$ & 231 bA & $236.2 \mathrm{bA}$ & $116.5 \mathrm{bB}$ & $172.5 \mathrm{aA}$ \\
\hline Carfentrazone & 78 abA & $33 \mathrm{aB}$ & 227 bA & $213.7 \mathrm{bA}$ & $128.7 \mathrm{bB}$ & $184.3 \mathrm{aA}$ \\
\hline CV A (\%) & \multicolumn{2}{|c|}{17.29} & \multicolumn{2}{|c|}{4.22} & \multicolumn{2}{|c|}{11.30} \\
\hline CV B (\%) & \multicolumn{2}{|c|}{16.90} & \multicolumn{2}{|c|}{3.98} & \multicolumn{2}{|c|}{9.95} \\
\hline
\end{tabular}

${ }^{1}$ Glufosinate ammonium

${ }^{2}$ Mean values followed by the same lowercase letters in the columns and uppercase letters in the rows are statistically equal by the Tukey test $(p \leq 0.05)$. 
For both evaluation periods, the seeds from the treatment with glufosinate ammonium exhibited changes in membrane integrity, whereas the seeds from the treatments with the other herbicides did not differ from each other for EC (Table 4). After storage, the EC values were higher than those found at the time of harvest. According to Moura et al. (2017), the greater the EC, the lower seed vigor is, because conductivity is a direct result of leachates.

The increase in electrical conductivity after storage may be related to damage, such as cracks, microfissures, and disorganization in seed cells, factors which contribute to an increase in EC values (Zucareli et al., 2015).

Information associated with the intensity, hue, and lightness of color is important for evaluation of cowpea. The added value of the product is related to the quality of the grain that is recently harvested and stored for a certain period. The chroma " $\mathrm{C}$ " defines the intensity of the color. In this respect, there was difference among the treatments at the time of harvest and after storage (Table 5). The treatments under saflufenacil had the greatest chroma; all the other treatments led to color of lesser intensity. Thus, saflufenacil can change cowpea seed color. After storage, there was reduction in " $C$ " values in all the treatments.

The hue angle " $\mathrm{h}$ " is used to define the hue of the seeds, and significant interaction was observed among the treatments (Table 5). Statistical differences in this aspect of seed color were not observed after harvest for the different herbicide treatments, though after storage, lower values were observed for the saflufenacil and glufosinate ammonium treatments (Table 5). After storage, there was change in the hue of the seeds from the control and from the seeds coming from plants treated with flumioxazin and carfentrazone. Change in the hue of seeds is possibly associated with biochemical changes that occurred in the seeds, and these changes were able to affect the other technological variables, such as seed color intensity and lightness, which define seed coat color.

Lightness in color of the grain, expressed by the " $\mathrm{L}$ " coordinate, is desired by the consumer and implies acceptance of the product. When harvested, regardless of the desiccant treatments, the seeds had " $\mathrm{L}$ " values near 50 . After storage, there was reduction to values from 26.12 to 28.03 (Table 5). This is related to reduction in quality and to the need for longer cooking time. The nearer the value is to 50, the better the quality (Ganascini et al., 2014). Environmental and genetic factors are responsible for bean seed coat darkening (Coutin et al., 2017).

The low yield of the cowpea crop is still one of the problems faced by growers, and this limitation may be related to the low physiological and genetic quality of the seeds. In this respect, studies on the time of desiccation after plant physiological maturity, spray volume for desiccation, and the spray tips used are fundamental for maintaining physiological quality of seeds for formation of viable seedlings.

Table 5. Chroma (C), hue angle $\left({ }^{\circ} \mathrm{h}\right)$, and $\mathrm{L}$ coordinate of cowpea seeds evaluated after harvest and after six months of storage $(6 \mathrm{MO})$ as a result of desiccant herbicide treatments.

\begin{tabular}{|c|c|c|c|c|c|c|}
\hline \multirow{2}{*}{ Desiccant } & \multicolumn{2}{|c|}{ C } & \multicolumn{2}{|c|}{${ }^{\circ} \mathrm{h}$} & \multicolumn{2}{|c|}{$\mathrm{L}$} \\
\hline & Harvest & $6 \mathrm{MO}$ & Harvest & $6 \mathrm{MO}$ & Harvest & $6 \mathrm{MO}$ \\
\hline Control & $20.31 \mathrm{abA}^{1 /}$ & $4.27 \mathrm{aB}$ & $1.30 \mathrm{aB}$ & $1.40 \mathrm{aA}$ & 47.99 abcA & $28.03 \mathrm{aB}$ \\
\hline Flumioxazin & $21.81 \mathrm{abA}$ & $4.11 \mathrm{aB}$ & $1.31 \mathrm{aB}$ & $1.40 \mathrm{aA}$ & $50.10 \mathrm{aA}$ & $27.06 \mathrm{aB}$ \\
\hline Glufosinate ammonium & $22.02 \mathrm{abA}$ & $4.74 \mathrm{aB}$ & $1.28 \mathrm{aA}$ & $1.30 \mathrm{bA}$ & $46.45 \mathrm{abcA}$ & $26.47 \mathrm{aB}$ \\
\hline Paraquat & 20.39 abA & $5.10 \mathrm{aB}$ & $1.32 \mathrm{aA}$ & $1.36 \mathrm{abA}$ & $44.77 \mathrm{cA}$ & $26.16 \mathrm{aB}$ \\
\hline Saflufenacil & $22.35 \mathrm{aA}$ & $4.95 \mathrm{aB}$ & $1.29 \mathrm{aA}$ & $1.31 \mathrm{bA}$ & $45.49 \mathrm{bcA}$ & $26.72 \mathrm{aB}$ \\
\hline Carfentrazone & $19.41 \mathrm{bA}$ & $4.11 \mathrm{aB}$ & $1.32 \mathrm{aB}$ & $1.40 \mathrm{aA}$ & $48.90 \mathrm{abA}$ & $27.48 \mathrm{aB}$ \\
\hline CV A (\%) & \multicolumn{2}{|c|}{9.76} & \multicolumn{2}{|c|}{2.31} & \multicolumn{2}{|c|}{4.23} \\
\hline CV B (\%) & \multicolumn{2}{|c|}{8.23} & \multicolumn{2}{|c|}{2.43} & \multicolumn{2}{|c|}{4.71} \\
\hline
\end{tabular}

${ }^{1}$ Mean values followed by the same lowercase letters in the columns and uppercase letters in the rows are statistically equal by the Tukey test $(p \leq 0.05)$. 


\section{CONCLUSIONS}

Desiccant herbicides applied on 'BRS Guariba' cowpea in the R5 maturity stage allow harvest to occur earlier, reduce yield and seed weight, and affect seed classification.

Desiccant herbicides affect seed quality. Glufosinate ammonium compromises seedling vigor, and flumioxazin affects cowpea seed quality.

\section{ACKNOWLEDGMENTS}

This study was carried out with the support of the Coordenação de Aperfeiçoamento de Pessoal de Nível Superior (CAPES) under funding code 001, and the support of the Instituto Federal de Goiano, Campus Rio Verde, GO, Brazil.

\section{REFERENCES}

AFONSO-JÚNIOR, P.C.; CORRÊA, P.C. Influência do tempo de armazenagem na cor dos grãos de café pré-processados por "via seca" e "via úmida". Ciência e Agrotecnologia, v.27, n.6, p.1268-1276, 2003. http://dx.doi.org/10.1590/S1413-70542003000600010

BOIAGO, N.P.; FORTES, A.M.T.; KULZER, S.R.; KOELLN, F.T.S. Potencial fisiológico de sementes armazenadas de cultivares de feijãocaupi produzidas no estado do Paraná. Revista Varia Scientia Agrárias, v.3, n.2, p.21-32, 2013. http://e-revista.unioeste.br/index. php/variascientiaagraria/article/view/6067

BRASIL. Ministério da Agricultura, Pecuária e Abastecimento. Regras para análise de sementes. Ministério da Agricultura, Pecuária e Abastecimento. Secretaria de Defesa Agropecuária. Brasília: MAPA/ACS, 2009. 395p. https://www.abrates.org.br/files/regras_ analise_de_sementes.pdf

CARVALHO, N.M.; NAKAGAWA, J. Sementes: ciência, tecnologia e produção. 4 ed. Jaboticabal: FUNEP, 2012. 588p.

CONAB. Companhia Nacional de Abastecimento. Acompanhamento da safra brasileira: 60 levantamento de grãos. Safra 2018/2019. Brasília: CONAB, 2019. 149p. https://www.conab.gov.br/info-agro/safras/graos/boletim-da-safra-de-graos

COUTIN, J.A.F.; MUNHOLLAND, S.; SILVA, A.; SUBEDI, S.; LUKENS, L.; CROSBY, W.L.; PAULS, K.P.; BOZZO, G.G. Proanthocyanidin accumulation and transcriptional responses in the seed coat of cranberry beans (Phaseolus vulgaris L.) with different susceptibility to postharvest darkening. BioMed Central Plant Biology, v.17, n.89, p.1-23, 2017. https://bmcplantbiol.biomedcentral.com/ articles/10.1186/s12870-017-1037-z

DELGADO, C.M.L.; COELHO, C.M.M.; BUBA, G.P. Mobilization of reserves and vigor of soybean seeds under desiccation with glufosinate ammonium. Journal of Seed Science, v.37, n.2, p.154-161, 2015. http://dx.doi.org/10.1590/2317-1545v37n2148445

EL-REFAI, A.A.; HARRAS, H.M.; EL-NEMR, K.M.; NOAMAN, M.A. Chemical and technological studies on faba bean seeds. Effect of storage on some physical and chemical properties. Food Chemistry, v.29, n.1, p.27-39, 1988. https://doi.org/10.1016/0308$8146(88) 90073-8$

FINOTO, E.L.; SEDIYAMA, T; ALBUQUERQUE, J.A.A.; SOARES, M.B.B.; GALLI, J.A.; CORDEIRO-JUNIOR, P.S.; MENEZES, P.H.S. Antecipação e retardamento de colheita nos teores de óleo e proteína das sementes de soja, cultivar Valiosa RR. Scientia Agropecuaria, v.8, n.2, p.99-107, 2017. http://revistas.unitru.edu.pe/index.php/scientiaagrop/article/view/1409

GANASCINI, D.; WUNSH, C.A.; SCHOENINGER, V.; SONCELA, R.F.; BISCHOFF, T.Z.; COELHO, S.R.; GURGACZ, F. Tempo de cozimento em três diferentes variedades de feijão carioca. Acta Iguazu, v.3, n.4, p.99-103, 2014. http://e-revista.unioeste.br/index.php/ actaiguazu/article/view/14505/9834

KAPPES, C.; ARF, O.; FERREIRA, J.P.; PORTUGAL, J.R.; ALCALDE, A.M.; ARF, M.V.; VILELA, R.G. Qualidade fisiológica de sementes e crescimento de plântulas de feijoeiro, em função de aplicações de paraquat em pré-colheita. Pesquisa Agropecuária Tropical, v.42, n.1, p.9-18, 2012. http://dx.doi.org/10.1590/S1983-40632012000100002

KNABBEN, C.C.; COSTA, J.S. Manual de classificação do feijão. Instrução normativa no 12, de 28 de março de 2008. Brasília, DF: Embrapa, 2012. 25p. https://ainfo.cnptia.embrapa.br/digital/bitstream/item/101039/1/manualilustrado-06.pdf 
KRZYZANOWSKI, F.C.; HENNING, A.A.; FRANÇA-NETO, J.B.; LORINI, I.; HENNING, F.A.; GAZZIERO, D.L.P. Tecnologias para produção de sementes de soja. Londrina: Embrapa Soja, 2015. 30p. https://www.embrapa.br/busca-de-publicacoes/-/publicacao/1006543/ tecnologias-para-producao-de-sementes-de-soja

LAMEGO, F.P.I.; GALLON, M.I.; BASSO, C.J.I.; KULCZYNSKI, S.M.I.; RUCHEL, Q.; KASPARY, T.; SANTI, A.L. Dessecação pré-colheita e efeitos sobre a produtividade e qualidade fisiológica de sementes de soja. Planta Daninha, v.31, n.4, p.929-938, 2013. http:// dx.doi.org/10.1590/S0100-83582013000400019

LIMA, H.M.; SCHUCH, L.O.B.; MENEGHELLO, G.E.; AUMONDE, T.Z.; PEDO, T. Qualidade fisiológica de sementes de feijão em função da dessecação química das plantas. Revista Científica Rural, v.20, n.2, p.180-187, 2018. http://revista.urcamp.tche.br/index.php/ $\mathrm{RCR} /$ article/view/259/pdf

MAGUIRE, J.D. Speed of germination aid in selection and evaluation for seedling emergence vigor. Crop Science, v.2, n.2, p.176-177, 1962.

MARCOS-FILHO, J. Fisiologia de sementes de plantas cultivadas. Londrina: ABRATES, 2015. 660p.

MARCOS-FILHO, J. Teste de envelhecimento acelerado. In: KRZYZANOWSKI, F.C.; VIEIRA, R.D.; FRANÇA-NETO, J.B. (ed.). Vigor de sementes: conceitos e testes. Londrina: ABRATES, 1999. p.1-24.

MATHIAS, V.; COELHO, C.M.M. Rendimento por peneiras de classificação e vigor em resposta às épocas de colheita de sementes de soja. Revista de Ciências Agrárias, v.61, p.1-6, 2018. https://ajaes.ufra.edu.br/index.php/ajaes/article/view/2619/1515

MOURA, M.C.F.; LIMA, L.K.S.; SANTOS, C.C.; DUTRA, A.S. Teste da condutividade elétrica na avaliação fisiológica em sementes de Vigna unguiculata. Revista de Ciências Agrárias, v.40, n.4, p.714-721, 2017. https://revistas.rcaap.pt/rca/article/view/16512/13454

MOUSSA, B.; LOWENBERG-DEBOER, J.; FULTON, J.; BOYS, K. The economic impact of cowpea research in West and Central Africa: a regional impact assessment of improved cowpea storage technologies. Journal of Stored Products Research, v.47, n.3, p.147-156, 2011. https://doi.org/10.1016/j.jspr.2011.02.001

NASAR-ABBAS, S.M.; PLUMMER, J.A.; SIDDIQUE, K.H.M.; WHITE, P.; HARRIS, D.; DODS, K. Cooking quality of faba bean after storage at high temperature and the role of lignins and other phenolics in bean hardening. Food Science and Technology, v.41, n.7, p.12601267, 2008. https://doi.org/10.1016/j.Iwt.2007.07.017

PAIVA, E.P.; SÁ, F.V.S.; TORRES, S.B.; BRITO, M.E.B.; MOREIRA, R.C.L.; SILVA, L.A. Germination and tolerance of cowpea (Vigna unguiculata) cultivars to water stress. Revista Brasileira de Engenharia Agrícola e Ambiental, v.22, n.6, p.407-411, 2018. http:// dx.doi.org/10.1590/1807-1929/agriambi.v22n6p407-411

SILVA, I.F.; FENILLI-JUNIOR, A.; LORENZETTI, E. Efeito de dessecantes na produtividade e qualidade fisiológica de sementes de soja. Revista Cultivando o Saber, v.9, n.3, p.224-242, 2016. https://www.researchgate.net/publication/313741415_Efeito_de_ dessecantes_na_produtividade_e_qualidade_fisiologica_de_sementes_de_soja

SOUZA, D.M.G.; LOBATO, E. (ed.). Cerrado: correção do solo e adubação. 2.ed. Brasília, DF: Embrapa Informação Tecnológica; Planaltina, DF: Embrapa Cerrados, 2004. 416p.

SOUZA, E.S.; ALVES, A.M.; PIEROZZI, C.G. Qualidade fisiológica de sementes de soja oriundas de campos dessecados com glufosinatosal de amônio e paraquat. Revista Agri-Environmental Sciences, v.3, n.2, p.40-46, 2017. https://revista.unitins.br/index.php/agrienvironmental-sciences/article/view/508

TARUMOTO, M.B.; CARVALHO, F.T.; ARF, O.; SILVA, P.H.F; PEREIRA, J.C.; BORTOLHEIRO, F.P.A.P. Dessecação em pré-colheita no potencial fisiológico de sementes e desenvolvimento inicial de trigo. Revista Cultura Agronômica, v.24, n.4, p.369-380, 2015. https://ojs.unesp.br/index.php/rculturaagronomica/article/view/2276

TAVARES, C.J.; FERREIRA, P.C.; JAKELAITIS, A.; SALES, J.F.; RESENDE, O. Physiological and sanitary quality of desiccated and stored azuki bean seeds. Revista Caatinga, v.29, n.1, p.66-75, 2016. http://dx.doi.org/10.1590/1983-21252016v29n108rc

VANZOLINI, S.; ARAKI, C.A.S.; SILVA, A.C.T.M.; NAKAGAWA, J. Teste de comprimento de plântula na avaliação da qualidade fisiológica de sementes de soja. Revista Brasileira de Sementes, v.29, n.2, p.90-96, 2007. http://dx.doi.org/10.1590/S0101-31222007000200012

VIEIRA, R.D.; KRZYZANOWISKI, F.C. Teste de condutividade elétrica. In: KRZYZANOWISKI, F.C.; VIEIRA, R.D; FRANÇA-NETO, J.B. (ed.). Vigor de sementes: conceitos e testes. Londrina: ABRATES, 1999. p.1-26. 
ZUCARELI, C.; BRZEZINSKI, C.R.; ABATI, J.; WERNER, F.; RAMOS-JÚNIOR, E.U.; NAKAGAWA, J. Qualidade fisiológica de sementes de feijão carioca armazenadas em diferentes ambientes. Revista Brasileira de Engenharia Agrícola e Ambiental, v.19, n.8, p.803-809, 2015. http://dx.doi.org/10.1590/1807-1929/agriambi.v19n8p803-809

ZUCHI, J.; FRANÇA-NETO, J.B.; SEDIYAMA, C.S.; LACERDA-FILHO, A.F.; REIS, M.S. Physiological quality of dynamically cooled and stored soybean seeds. Journal of Seed Science, v.35, n.3, p.353-360, 2013. http://dx.doi.org/10.1590/S2317-15372013000300012 use, distribution, and reproduction in any medium, provided the original work is properly cited. 